\title{
Relationship between tetracycline antibiotic susceptibility and genotype in oral cavity Lactobacilli clinical isolates
}

\author{
Yifei Zhang and Qian Zhang*
}

\begin{abstract}
Background: Antibiotic resistance, is often conferred by the presence of antibiotic resistance genes. This study aimed to investigate the relationship between tetracycline resistance (Tet-R) and genotype in 31 Lactobacillus isolates from caries-active patients.

Methods: The tetracycline susceptibility of Lactobacillus isolates was determined using the agar spot test and the genetic characteristics associated with tetracycline resistance using whole-genome sequencing (WGS).

Results: The minimum inhibitory concentration (MIC) values of most isolates were equal to or lower than the breakpoint MIC values. Four strains that were phenotypically more sensitive (L. fermentum B09, S23 and L.

rhamonsus B17) or more resistant (L. plantarum B43) than other isolates to tetracycline were subjected to conduct whole-genome sequencing in order to detect the tetracycline resistance genes. The results revealed that the most common Tet-R genes in Lactobacillus strains were tet $\mathrm{T}$, tet $\mathrm{W}$, tetO and tetL. In addition, tetPB, tcr3 and otrA were detected for the first time. There were distinct Tet-R gene mutations in Lactobacillus isolates. Overall, the mean expression values of Tet-R-mutated genes in L. plantarum B43 were elevated, and the relative expression levels of tet T and tetW genes in L. rhamonsus B17 L. fermentum B09 and S23 were decreased relative to reference strains.

Conclusion: The results of this study indicate that Lactobacillus isolates from saliva of caries-active patients do not present considerable tetracycline resistance reservoirs. However, genetic compounds associated with tetracycline resistance were identified by whole-genome sequencing, providing meaningful insights into tetracycline resistance mechanisms.
\end{abstract}

Keywords: Tetracycline resistance, Minimum inhibitory concentration, Whole-genome sequencing

\section{Background}

Antibiotic resistance has become a major global public health problem [1]. It is often conferred by the presence of antibiotic resistance genes, which may spread rapidly through horizontal gene transfer via plasmids and other genetic elements, and can result the environmental contamination with antibiotic resistance strains [2]. At present, there is great concern that commensal bacterial populations, such as lactic acid bacteria from food and the intestines of animals can carry and transmit antibiotic-resistance genes [3-6]. The oral cavity

\footnotetext{
* Correspondence: zhangqian860203@163.com

Central Laboratory, Peking University School and Hospital of Stomatology \& National Engineering Laboratory for Digital and Material Technology of Stomatology \& Beijing Key Laboratory of Digital Stomatology, Beijing, People's Republic of China
}

represents a dynamic and complex microbial community, in which more than 700 microorganisms reside [7]. As a portal that connects the environment to the digestive tract, the oral cavity frequently comes into contact with other bacteria from the environment, and oral bacteria can easily reach other sites of the body and spread to other individuals. Therefore, oral bacteria have the opportunity to acquire and transfer antibioticresistant genes $[8,9]$. A number of individual bacterial isolates with resistance to one or more antibiotics have been isolated from the oral cavity of both patients and healthy subjects [10-12]. The presence of genes encoding antibiotic resistance in the oral microbiota has also been recorded [13].

(c) The Author(s). 2019 Open Access This article is distributed under the terms of the Creative Commons Attribution 4.0 International License (http://creativecommons.org/licenses/by/4.0/), which permits unrestricted use, distribution, and reproduction in any medium, provided you give appropriate credit to the original author(s) and the source, provide a link to the Creative Commons license, and indicate if changes were made. The Creative Commons Public Domain Dedication waiver (http://creativecommons.org/publicdomain/zero/1.0/) applies to the data made available in this article, unless otherwise stated. 
Lactobacilli are members of the lactic acid bacteria community, which can adapt to a wide variety of ecological niches (e.g., food, oral cavity, gastro-intestinal tract, and vagina) [14]. In the oral cavity, Lactobacilli level reflects the caries activity of an individual, since it is highly prevalent in subjects with caries-active lesions, while those who remain caries-free generally harbor low levels of Lactobacilli in their mouth $[15,16]$. The dominant species in both adult and childhood caries include Lactobacillus fermentum, Lactobacillus rhamnosus, Lactobacillus plantarum, Lactobacillus gasseri, Lactobacillus casei/paracasei, and Lactobacillus salivarius $[15,17,18]$. Some Lactobacilli strains are marked as probiotics and are utilized in industrial and medical or health-related settings $[19,20]$. The antibiotic resistance genes located on mobile elements (plasmids, transposons and integrons) can be transferred horizontally. As members of oral microbial communities, the Lactobacillus strains have the opportunity to exchange resistance factors with other microorganisms [21], potentially transferring these genes to other pathogenic bacteria. Furthermore, the emergence of Lactobacilli as reservoirs of antibiotic resistance genes could represent a threat to human health if antibiotic resistant oral-derived Lactobacilli are used as probiotic or swallowed into intestine, and this issue may exacerbated the concomitant antibiotic therapy and transfer of resistance genes to intestinal bacteria [22]. Additionally, oral-derived Lactobacilli have the opportunity to transfer from person to person, which could further promote the spread of a resistant strain to new hosts and subsequent dissemination of the transferable antibiotic resistance to susceptible bacteria. Thus, it is essential to check for signs of transferable antibiotic resistance in Lactobacilli strains that are important in oral cavity, and in strains that are used as probiotics.

Tetracycline is a broad-spectrum antibiotic that is used for the treatment of a variety of Gram-positive and -negative bacterial infections. Tetracycline resistance (Tet-R) in most bacteria is due to the acquisition of genes encoding energy-dependent efflux pumps, ribosomal protection proteins (RPPs), or enzymatic inactivation [23], many of which are related to the Tn916-Tn1545 family of transposable elements and plasmids $[9,24,25]$. The mobile elements encoding Tet- $\mathrm{R}$ genes are widely distributed in oral species [26-29]. Here, we conducted phenotypic and genetic analyses of Tet- $\mathrm{R}$ in Lactobacilli clinical isolates from caries-active patients.

In this study, we explored the tetracycline susceptibility of isolated Lactobacillus clinical strains and identified the genetic characteristics associated with tetracycline resistance using whole-genome sequencing.

\section{Methods}

\section{Lactobacillus strains and cultivation}

A total of 31 Lactobacillus clinical strains isolated from caries-active patients [14] were selected, containing Lactobacillus fermentum $(n=17)$, Lactobacillus rhamonsus ( $n$ $=7)$, and Lactobacillus plantarum $(n=7)$. Three Lactobacillus reference strains (L. fermentum ATCC 14931, L. rhamnosus ATCC 7469, and L. plantarum ATCC 8014) were used as controls. Isolates were grown in De Man, Rogosa, and Sharpe (MRS) medium (Hopebio, China) at $37^{\circ} \mathrm{C}$ in an atmosphere of $5 \% \mathrm{CO}_{2}$ and $95 \%$ air.

\section{Antibiotic susceptibility testing and MIC determination}

An agar dilution method was used for testing the antibiotic susceptibility of isolates according to the Clinical \& Laboratory Standards Institute (CLSI) guidelines, in which Mueller-Hinton medium was replaced by MRS agar [30]. For the production of the test plates, tetracycline hydrochloride stock solutions were prepared and diluted in sterile distilled water to obtain a series of tetracycline solutions with twofold concentrations from 160 to $5120 \mu \mathrm{g} / \mathrm{mL}$. First, $2 \mathrm{~mL}$ antibiotic solution was mixed with $18 \mathrm{~mL}$ MRS agar to obtain test plates of the final range $(2 \sim 512 \mu \mathrm{g} / \mathrm{mL})$. Individual colonies of each Lactobacillus strain were grown in MRS broth to obtain a density corresponding to $\mathrm{OD}_{630}=0.02$ (approximately $5 \times 10^{8}$ colony-forming units $/ \mathrm{mL}$ ). Then, $10 \mu \mathrm{L}$ of bacterial solution was inoculated on each test plate. The plate without tetracycline was used as control. After $20 \sim 24 \mathrm{~h}$ incubation at $37{ }^{\circ} \mathrm{C}$ in an atmosphere of $5 \%$ $\mathrm{CO}_{2}$ and $95 \%$ air, the plate with lowest tetracycline concentration producing lower than thirty colony was determined and defined as the minimum inhibitory concentration (MIC) of each strain. The strains with MIC values lower than or equal to the microbiological breakpoints for anti-tetracycline $(8 \mu \mathrm{g} / \mathrm{mL}$ for L. fermentum and L. rhamonsus; and $32 \mu \mathrm{g} / \mathrm{mL}$ for L.plantarum) [31] were defined as susceptible. Three independent biological replicates were performed.

\section{DNA extraction and Illumina HiSeq sequencing}

According to MIC values, four Lactobacillus clinical isolates, which were phenotypically more sensitive ( $L$. fermentum B09, S23 and L. rhamonsus B17) or more resistant (L. plantarum B43) than other isolates to tetracycline were subjected to conduct WGS to detect the Tet-R genes. First, Bacterial genomic DNA was extracted with a TIANamp Bacteria DNA Kit (Tiangen Biotech Co., Ltd., China) according to the manufacturer's instructions. Genomic DNA was evaluated and quantified using a Nanodrop 8000 instrument and Qubit 3.0 fluorometer (Thermo Scientific, USA). High-quality DNA samples $\left(\mathrm{OD}_{260} / \mathrm{OD}_{280}=1.8 \sim 2.0,>1 \mu \mathrm{g}\right)$ were utilized to construct the fragment library. 
Purified genomic DNA was sheared into $300-500 \mathrm{bp}$ fragments by sonication, and the library was then constructed following the Illumina TruSeq ${ }^{\mathrm{Tm}}$ Nano DNA Sample Prep Kit instruction (Illumina, USA). The index tag was introduced into the adapter at the PCR stage when appropriate. The high quality Illumina pair-end library $(2 \times 150 \mathrm{bp})$ was sequenced with the Illumina HiSeq platform.

\section{Genome assembly and SNP analysis}

We used ABySS (http://www.bcgsc.ca/platform/bioinfo/ software/abyss) and GapCloser software (https://sourceforge.net/projects/soapdenovo2/files/GapCloser/) to perform genome assembly with multiple-kmer parameters based on the high-quality data for the final assembly results.

The MUMmer blast software was used for SNP analysis. L. fermentum ATCC 14931 (NZ_GG669901.1) was selected as the reference strain for $L$. fermentum clinical strain B09 and S23; L. rhamnosus ATCC 53013 (NC_017482.1) was selected as the reference strain for $L$. rhamnosus clinical strain B17 and L. plantarum ATCC 8014 (NZ_CP024413.1) was selected as the reference strain for L. plantarum clinical strain B43. All of the sequences were blasted with the Comprehensive Antibiotic Resistance Database (CARD).

\section{Real-time RT-PCR}

RNA was extracted from four Lactobacillus clinical isolates and corresponding reference strains following the RNeasy Mini Kit (Qiagen, USA) following the instructions. RNA was quantified using Nanodrop 8000 spectrophotometer. $1 \mu \mathrm{g}$ RNA was treated with DNase I and reverse-transcribed with ReverTra Ace qPCR RT Master Mix (Toyobo,Japan). Quantitative real time polymerase chain reaction (qPCR) was performed using PowerUp SYBR Green Master Mix in an ABI 7500 system (Thermo Scientific, USA). Primers sequences were designed and listed in Table 1. All reaction volumes were $20 \mu \mathrm{l}$ and underwent the following reaction condition: initial denaturation for $10 \mathrm{~min}$ at $95^{\circ} \mathrm{C}$, followed by 40 cycles of $10 \mathrm{~s}$ at $95^{\circ} \mathrm{C}$ and $1 \mathrm{~min}$ at $55^{\circ} \mathrm{C}$ for fluorescence collection, with extension of $1 \mathrm{~min}$ at $72^{\circ} \mathrm{C}$. The bacterial 16S rRNA gene was used as a reference for calculating target gene expression. The qPCR was carried out in technical triplicates. The relative expression of tet genes was calculated by the $2^{-\Delta \Delta \mathrm{Ct}}$ method.

\section{Results}

\section{Antimicrobial susceptibility}

The MIC of each Lactobacillus strain is summarized in Table 2. A narrow range of MIC values was exhibited by most $L$. fermentum and $L$. rhamonsus strains $(4-8 \mu \mathrm{g} /$ $\mathrm{mL}$ ), except for three strains ( $L$. fermentum B09, $L$. fermentum S23 and L. rhamonsus B17) with a MIC lower than $2 \mu \mathrm{g} / \mathrm{mL}$ and a L. rhamonsus strain B22 with the MIC value of $16 \mu \mathrm{g} / \mathrm{mL}$. All $L$. plantarum strains displayed higher MIC values than $L$. fermentum and $L$. rhamonsus, ranging from 16 to $32 \mu \mathrm{g} / \mathrm{mL}$, except for one strain (B43) with a MIC higher than $64 \mu \mathrm{g} / \mathrm{mL}$. According to the microbiological breakpoints for anti-tetracycline defined in [31], only L. rhamonsus B22 and L. plantarum B43 displayed resistance to tetracycline.

\section{Detection of putative tetracycline resistance genes}

The whole genome sequences were obtained by assembling clean reads $(11,590,856$ reads for B09, 14,537,793 reads for S23, 19,571,983 reads for B17, and 11,723,377 reads for B43; Average coverage $>500$ folds), and the results were compared with corresponding reference strains and CARD. All selected genes were identified using the following criteria of e-value $<1 \mathrm{e}-20$, sequence identify was higher $20 \%$ and bit scores $>50$ [32]. The WGS data are available from the Sequence Read Archive under accession numbers SRR8300881, SRR8300882, SRR8300883, SRR8300884. The four isolates had the same Tet-R genes as corresponding reference strains, in terms of gene type. No gene deletion or exogenous Tet- $R$ genes were detected. The most common Tet- $R$ genes in Lactobacillus strains were tet $\mathrm{T}$, tet $\mathrm{W}$, tet $\mathrm{O}$ and tet $\mathrm{L}$. Some new Tet- $\mathrm{R}$ genes were also detected, such as: tet $\mathrm{PB}, t c r 3$ and otr $\mathrm{A}$ (Table 3), which may be responsible for the molecular tetracycline resistance determinants. We also found that $t e t \mathrm{~T}, t e t \mathrm{~W}$ and $\operatorname{tet} \mathrm{O}$ genes, which have previously been investigated in Lactobacilli were more diverse and displayed low homology among different isolates.

To identify the changes responsible for Tet-R, we further analyzed single nucleotide variations in Tet-R genes of high-susceptible (B09/S23 and B17) and resistant isolates (B43) (Table 3). B09 exhibited 16 nonsynonymous mutations in five Tet- $\mathrm{R}$ genes $(\operatorname{tet} \mathrm{PB}$, tet $\mathrm{T}$, tet $\mathrm{W}$, otrA and tcr3), S23 exhibited the same variations as B09 in relation to the reference genomes (ATCC14931). Interestingly, both B09 and S23 contained a 12 bp deletion at the 122,242 position. Mapping the B17 sequence results against with the reference genome (ATCC53103) showed that there were 10 nonsynonymous mutations in four Tet- $\mathrm{R}$ genes $($ tet $\mathrm{W}$, tet $\mathrm{O}, t \operatorname{tc} 3$ and $\operatorname{tet} \mathrm{T})$ in strain B17; it also confirmed that B43 exhibited 22 nonsynonymous mutations in five Tet- $\mathrm{R}$ genes $($ tet $\mathrm{T}, t c r 3$, tet $\mathrm{O}$, tet $\mathrm{PB}$ and tet $\mathrm{L})$, compared to the reference genome (ATCC8014).

\section{Expression analysis of Tet-R mutation gene}

To reveal the relationship between genetic variation and antimicrobial susceptibility, we utilized qRT-PCR to determine the expression of mutant Tet- $R$ genes in 
Table 1 Primers for the detected Tet-R genes in selected clinical isolates and ATCC strains

\begin{tabular}{|c|c|c|c|}
\hline Bacteria & Genes & Primers $\left(5^{\prime}-3^{\prime}\right)$ & Amplified length (bp) \\
\hline \multirow[t]{14}{*}{ L. fermentum } & \multirow[t]{2}{*}{ tetPB } & F:AACTTACCCGATGGACTGGC & \multirow[t]{2}{*}{146} \\
\hline & & R:CCCCAATCACTTCCCCGTTT & \\
\hline & \multirow[t]{2}{*}{ tet $\mathrm{T}$} & F:CGACCCTATCCGAAGCCCTCT & \multirow[t]{2}{*}{153} \\
\hline & & R:GGGCGTATCTAGGAGGGTGAGTT & \\
\hline & \multirow[t]{2}{*}{ otrA1 } & F:GCCGTTACCGTTAGCATTAG & \multirow[t]{2}{*}{195} \\
\hline & & R:TAACTTAGCCAAAAAGGAGGGGATG & \\
\hline & \multirow[t]{2}{*}{ otrA2 } & F:ATAGCGGAGGCGTAAACTACTGGG & \multirow[t]{2}{*}{166} \\
\hline & & R:TAAAGAAGGCCCTGGAACAACAC & \\
\hline & \multirow[t]{2}{*}{ tetW1 } & F:ACGCTITGGAGTTGGGATGT & \multirow[t]{2}{*}{108} \\
\hline & & R:GTTGTTCGTGGGTCCGCTCTT & \\
\hline & \multirow[t]{2}{*}{ tetW2 } & F:GAAGGTCAGGGCGGCGTCGTT & \multirow[t]{2}{*}{108} \\
\hline & & R:ATGCAGCCAATGGTCTACGC & \\
\hline & \multirow[t]{2}{*}{$\operatorname{tcr} 3$} & F:GCGTTGGCTGAAGTAAAAGATGA & \multirow[t]{2}{*}{177} \\
\hline & & R:CCCCACAACGAAAACCCCCACTT & \\
\hline \multirow[t]{8}{*}{ L. rhamonsus } & \multirow[t]{2}{*}{ tetW } & F:GCAAGACTGCGACTAACTTCATAAC & \multirow[t]{2}{*}{161} \\
\hline & & R:GTTCTGGACGATATGGCACTTGA & \\
\hline & \multirow[t]{2}{*}{ tetO } & F:TGGCCTTCAATTCAAGCACATCT & \multirow[t]{2}{*}{113} \\
\hline & & R:AGACTGGGGTGGCGACACTATTT & \\
\hline & \multirow[t]{2}{*}{ tcr3 } & F: TAAGACGCCACTAAGCAGCAAAG & \multirow[t]{2}{*}{131} \\
\hline & & R:CCATTGTCGGCGGGTATCTGTTA & \\
\hline & \multirow[t]{2}{*}{ tet $\mathrm{T}$} & F:ATCACATTCTTCGGGGTTACACG & \multirow[t]{2}{*}{151} \\
\hline & & R:TACAGCGGTAGCAGGGGACATTG & \\
\hline \multirow[t]{12}{*}{ L.plantarum } & \multirow[t]{2}{*}{ tet $\mathrm{T}$} & F:CATTTGAACCGTTACGACACT & \multirow[t]{2}{*}{260} \\
\hline & & R:GTCGCTTCACGAAAGTCACCACC & \\
\hline & \multirow[t]{2}{*}{ tetO } & F:CCTITCCACGGTCAAGACTAGC & \multirow[t]{2}{*}{180} \\
\hline & & R:TCTGATTCCTGAAGATTGGGGTG & \\
\hline & \multirow[t]{2}{*}{ tetL } & F:TAACAAGTAAGCCGTGGTCATCC & 123 \\
\hline & & R:GGATTACTTTCATTITGCGGGGT & \\
\hline & $\operatorname{tcr} 3$ & F:GTCTCATTTGTTGCCGACACTTC & 135 \\
\hline & & R:TGTGCTGCCGTIIITTGTGGTCC & \\
\hline & tetPB & F:ACTTGGCAAACAGCGGGGACT & 144 \\
\hline & & R:CACTGACTTCATTAGCCATA & \\
\hline & $16 \mathrm{~s}$ rRNA & F:CCTACGGGAGGCAGCAGTAG & 101 \\
\hline & & R:CAACAGAGCTTTACGATCCGAAA & \\
\hline
\end{tabular}

susceptible/resistance isolates and reference strains. The relative expression levels of tetPB and tet $\mathrm{W} 1$ in B09 and $\mathrm{S} 23$; tet $\mathrm{O}$, tet $\mathrm{PB}$, tet $\mathrm{L}$ and $t$ tr 3 in $\mathrm{B} 43$ isolates were significantly increased compared to the respective reference strains. Also, the relative expression level of tet $\mathrm{T}$, tet $\mathrm{W} 2$, otr $\mathrm{A}$ and $t c r 3$ in $\mathrm{B} 09$ and $\mathrm{S} 23$, and of tet $\mathrm{W}$, tet $\mathrm{O}$ and tet $\mathrm{T}$ in $\mathrm{B} 17$ isolate, were significantly decreased compared to the respective reference strains. The remaining detected mutant Tet- $\mathrm{R}$ did not differ among the above three isolates. The relative expression of most of mutant Tet- $\mathrm{R}$ genes in the susceptible isolates (B09/
S23, B17) was down-regulated, while the relative expression in the resistance isolates (B43) was up-regulated.

\section{Discussion}

Tetracycline resistance genes commonly found on conjugative transposons of the $\operatorname{Tn} 916 / \operatorname{Tn} 1545$ family, are easily disseminated among bacteria. Devirgiliis et al. found that the conjugative transposon Tn916 carrying the tet $(M)$ gene can be interspecies transferred from $L$. paracasei isolates to the opportunistic pathogen Enterococcus faecalis [21]. Ready et al. observed the transfer of 
Table 2 The distribution of tetracycline resistance genes and the range of MIC among Lactobacillus isolates and ATCC strains

\begin{tabular}{|c|c|c|c|}
\hline \multicolumn{2}{|l|}{ Bacteria } & \multirow{2}{*}{$\begin{array}{l}\text { Breakpoints for Tetracycline } \\
\text { Resistance }(\mu \mathrm{g} / \mathrm{mL})(\text { EFSA, 2008) } \\
8\end{array}$} & \multirow{2}{*}{$\begin{array}{l}\mathrm{MIC} \\
(\mu \mathrm{g} / \mathrm{mL}) \\
<2\end{array}$} \\
\hline L. fermentum & $\mathrm{B} 09^{\mathrm{a}}$ & & \\
\hline & B58 & & 4 \\
\hline & B52 & & 4 \\
\hline & S19 & & 8 \\
\hline & B86 & & 4 \\
\hline & B77 & & 4 \\
\hline & $\mathrm{S} 12$ & & 4 \\
\hline & B16 & & 8 \\
\hline & B32 & & 8 \\
\hline & $\mathrm{B} 50$ & & 4 \\
\hline & B59 & & 4 \\
\hline & S29 & & 8 \\
\hline & $\mathrm{S} 23^{\mathrm{a}}$ & & $<2$ \\
\hline & B82 & & 8 \\
\hline & B48 & & 4 \\
\hline & B84 & & 4 \\
\hline & B36 & & 4 \\
\hline & ATCC14931 & & 16 \\
\hline \multirow[t]{8}{*}{ L. rhamonsus } & $\mathrm{B} 17^{\mathrm{a}}$ & 8 & $<2$ \\
\hline & B22 & & 16 \\
\hline & B37 & & 8 \\
\hline & B61 & & 8 \\
\hline & B71 & & 8 \\
\hline & S22 & & 8 \\
\hline & B18 & & 4 \\
\hline & ATCC53103 & & 8 \\
\hline \multirow[t]{8}{*}{ L.plantarum } & B01 & 32 & 16 \\
\hline & B14 & & 16 \\
\hline & B24 & & 16 \\
\hline & $\mathrm{B} 40$ & & 16 \\
\hline & B41 & & 16 \\
\hline & $\mathrm{B} 43^{\mathrm{a}}$ & & 64 \\
\hline & B68 & & 32 \\
\hline & ATCC8014 & & 16 \\
\hline
\end{tabular}

$\mathrm{a}_{\mathrm{i}}$ indicates the clinical isolates for whole-genome sequencing

Tn916-like elements between oral Veillonella spp. and Streptococci spp. [13]. It has been reported that Lactobacilli present in fermented foods or animal intestines may represent an important reservoir of transferable Tet- $\mathrm{R}$ genes $[4,33]$. However, according to other research, Lactobacilli clinical strains from food [34] and animal fecal microbiota $[35,36]$ do not present with considerable Tet-R and tet gene expression is rarely detected. We have reported for the first time the presence of
Tet- $\mathrm{R}$ in Lactobacilli isolates derived from human saliva. With the exception of the reference strain $L$. fermentum ATCC 14931 and tested strains L. rhamonsus B22 and $L$. plantarum B43, all tested strains remained tetracycline susceptible. Our results indicated that Lactobacilli isolates from the oral cavity showed a very low prevalence of resistance to tetracycline.

We then investigated the correlation between the phenotypic susceptibility of tetracycline and the existence of Tet- $R$ genes. The isolates investigated in this study, L. fermentum (B09, S23) and L. rhamonsus (B17) were phenotypically more sensitive (high-sensitive), while L. plantarum (B43) were more resistant (high-resistant) to tetracycline than other isolates. Jungermann et al. first reported the presence of tet $\mathrm{W}$ and tet $\mathrm{Q}$ in endodontic infections. They found that the tet $\mathrm{M}$ and tet $\mathrm{W}$ genes showed near-equal prevalence in root canal specimens with endodontic infections, and increased prevalence relative to tet $\mathrm{Q}$. After treatment, tet $\mathrm{W}$ and tet $\mathrm{Q}$ were significantly reduced, with no change in tet $\mathrm{M}$ [37]. Villedieu et al. reported that tet $\mathrm{W}$ was the second most common Tet- $\mathrm{R}$ gene in the oral microflora of healthy adults. It has also been shown that this gene is present in oral Lactobacillus species [38]. Another study confirmed that the tet $\mathrm{M}$ gene was more prevalent in asymptomatic cases, while tet $\mathrm{W}$ was more prevalent in acute apical abscess cases [28]. The presence of Tet- $R$ genes varied among different Lactobacillus species and in this study varied even within species in our investigation. According to previous studies, the most common Tet- $\mathrm{R}$ genes encoding a RPP or efflux protein, which were identified in foodborne or animal origin, were tet $\mathrm{M}$, tet $\mathrm{W}$, tet $\mathrm{K}$, tet $\mathrm{L}$, tet $\mathrm{S}$ and tet $\mathrm{O}[5,39]$. Also, tet $\mathrm{O}$ has been found in the plasmid of Streptococcus mutans, a pathogen related to caries [40]. Through wholegenome analysis, tet $\mathrm{T}$, tet $\mathrm{PA}$, tet $\mathrm{PB}$, tcr 3 , tet $\mathrm{W}$, tet $\mathrm{O}$, tet $\mathrm{L}$ and otrA were detected in our isolates. As far as we know, this is the first study of tet $\mathrm{PB}, t c r 3$ and otrA that detected in Lactobacillus species, highlighting the values of WGS as a tool for identifying new resistance genes. We did not find any exogenous Tet- $\mathrm{R}$ determinant in tested strains relative to the reference strains, revealing the low possibility of the horizontal transfer of Tet-R genes in saliva-derived Lactobacilli.

It has been reported that mutations in tet A encoding tetracycline efflux pumps can reduce sensitivity to glycylcycline, a novel class of tetracycline [41, 42]. Here, we identified new mutations in tet genes encoding RPP (e.g. tet $\mathrm{PB}$, tet $\mathrm{W}$, otr $\mathrm{A}$, tet $\mathrm{T}$ and $\operatorname{tet} \mathrm{O}$ ) that can affect gene expression. Note that in two unrelated L. fermentum strains B09 and S23, the exact same mutation is responsible for Tet-R, which opens possibility of developing molecular screening tests for Tet- $\mathrm{R}$ in L. fermentum. However, each strain has more than one Tet-R gene with 
Table 3 SNPs and relative expression of mutant Tet-R genes in selected four clinical isolates and ATCC strains

\begin{tabular}{|c|c|c|c|c|}
\hline Strains & $\begin{array}{l}\text { Predicted } \\
\text { Tet- } R \text { genes }\end{array}$ & $\begin{array}{l}\text { Position in } \\
\text { Reference }\end{array}$ & SNP & $\begin{array}{l}\text { Relative expression of } \\
\text { mutant Tet-R genes }\end{array}$ \\
\hline \multirow[t]{18}{*}{ B09/S23 } & \multirow[t]{2}{*}{ tetPB } & 57,351 & C to $T$ & \multirow[t]{2}{*}{$4.18 \pm 1.58 * / 3.87 \pm 0.32^{*}$} \\
\hline & & 57,574 & A to $T$ & \\
\hline & \multirow[t]{4}{*}{ tet $\mathrm{T}$} & 19,518 & $G$ to $A$ & \multirow[t]{4}{*}{$0.32 \pm 0.21 * / 0.12 \pm 0.04^{*}$} \\
\hline & & 20,404 & T to $C$ & \\
\hline & & 20,503 & A to $G$ & \\
\hline & & 21,180 & A to $G$ & \\
\hline & \multirow[t]{5}{*}{ otrA1 } & 121,289 & A to $G$ & \multirow[t]{5}{*}{$1.74 \pm 0.23 * / 0.71 \pm 0.17$} \\
\hline & & 121,893 & A to $G$ & \\
\hline & & 122,217 & A to $G$ & \\
\hline & & 122,373 & $\mathrm{G}$ to $\mathrm{A}$ & \\
\hline & & 122,475 & A to $G$ & \\
\hline & \multirow[t]{2}{*}{ tetW1 } & 201,420 & A to $C$ & \multirow[t]{2}{*}{$7.9 \pm 1.47^{*} / 1.54 \pm 0.12$} \\
\hline & & 201,567 & $G$ to $A$ & \\
\hline & \multirow[t]{2}{*}{ otrA2 } & 217,467 & $C$ to $T$ & \multirow[t]{2}{*}{$0.90 \pm 0.16 / 1.02 \pm 0.21$} \\
\hline & & 217,786 & G to $A$ & \\
\hline & tetw2 & 86,983 & A to $G$ & $0.53 \pm 0.89 / 0.61 \pm 0.12$ \\
\hline & \multirow[t]{2}{*}{$\operatorname{tcr} 3$} & 116,527 & G to $A$ & \multirow[t]{2}{*}{$0.49 \pm 0.03 / 0.65 \pm 0.15$} \\
\hline & & 117,173 & A to $G$ & \\
\hline \multirow[t]{8}{*}{ B17 } & tetw & $1,623,933$ & T to $A$ & $0.43 \pm 0.12^{*}$ \\
\hline & \multirow[t]{4}{*}{ tetO } & $1,636,215$ & $\mathrm{G}$ to $\mathrm{A}$ & \multirow[t]{4}{*}{$0.21 \pm 0.02^{*}$} \\
\hline & & $1,636,258$ & $C$ to $T$ & \\
\hline & & $1,636,464$ & $C$ to $G$ & \\
\hline & & $1,636,637$ & T to $\mathrm{G}$ & \\
\hline & tcr3 & 210,281 & G to $A$ & $1.63 \pm 3.10^{*}$ \\
\hline & \multirow[t]{2}{*}{ tet $\mathrm{T}$} & $1,850,771$ & T to $C$ & \multirow[t]{2}{*}{$0.13 \pm 0.01^{*}$} \\
\hline & & $1,851,067$ & A to $G$ & \\
\hline \multirow[t]{17}{*}{ B43 } & \multirow[t]{6}{*}{ tetT } & 89,875 & $\mathrm{G}$ to $\mathrm{A}$ & \multirow[t]{6}{*}{$1.21 \pm 0.29$} \\
\hline & & 90,659 & $C$ to $A$ & \\
\hline & & 90,711 & A to $G$ & \\
\hline & & 90,814 & $\mathrm{G}$ to $\mathrm{A}$ & \\
\hline & & 90,966 & $\mathrm{G}$ to $\mathrm{A}$ & \\
\hline & & 91,116 & T to $C$ & \\
\hline & \multirow[t]{4}{*}{ tetL } & $1,722,509$ & $C$ to $A$ & \multirow[t]{4}{*}{$5.03 \pm 0.95^{*}$} \\
\hline & & $1,722,558$ & A to $C$ & \\
\hline & & $1,722,936$ & A to $C$ & \\
\hline & & $1,722,984$ & G to $A$ & \\
\hline & \multirow[t]{4}{*}{ tetO } & $1,810,986$ & $C$ to $T$ & \multirow[t]{4}{*}{$2.05 \pm 0.49^{*}$} \\
\hline & & $1,811,028$ & $C$ to $G$ & \\
\hline & & $1,811,043$ & $\mathrm{G}$ to $\mathrm{A}$ & \\
\hline & & $1,811,052$ & $G$ to $A$ & \\
\hline & tcr3 & $1,178,583$ & $\mathrm{G}$ to $\mathrm{A}$ & $4.99 \pm 1.24^{*}$ \\
\hline & & $1,722,509$ & $C$ to $A$ & \\
\hline & & $1,722,558$ & A to $C$ & \\
\hline
\end{tabular}

Table 3 SNPs and relative expression of mutant Tet-R genes in selected four clinical isolates and ATCC strains (Continued)

\begin{tabular}{cllll}
\hline Strains & $\begin{array}{l}\text { Predicted } \\
\text { Tet-R genes }\end{array}$ & $\begin{array}{l}\text { Position in } \\
\text { Reference }\end{array}$ & SNP & $\begin{array}{l}\text { Relative expression of } \\
\text { mutant Tet-R genes }\end{array}$ \\
\hline \multirow{4}{*}{ tetPB } & $1,722,936$ & A to C & \\
$1,722,984$ & G to A & \\
& $2,686,361$ & T to A & $2.84 \pm 1.08^{*}$ \\
$2,686,721$ & C to A & \\
$2,686,722$ & G to A \\
& $2,686,946$ & T to $G$ \\
& $2,686,952$ & C to $T$ \\
& $2,687,201$ & C to $T$ \\
$2,687,423$ & G to A
\end{tabular}

* is represented the relative expression level of mutant Tet-R genes was significant difference between isolates and references strains.

mutation-dependent expression. Thus it is difficult to determine which Tet- $R$ gene mutant is responsible for the altered Tet-R. In B43 isolates of $L$ plantarum, the expression of all Tet- $R$ genes were up-regulated with the higher Tet-R. Most Tet-R genes in L. fermentum strains B09/S23 and L. rhamonsus B17 had lower mean expression, consistent with their tetracycline susceptibility, thus supporting our hypothesis. The expression levels of several Tet-R genes in our study were not consistent with the genotype, which is consistent with previous reports [43]. It is likely that the resistance level conferred by different Tet- $R$ genes is species and strain-dependent [44]. The two types of tet genes: active efflux and ribosomal protection, may play different physiological functions in the same isolates. Additionally, the expression of different Tet- $R$ genes may be induced at different tetracycline concentrations [44]. Moreover, genetic mutation may influence relevant enzymatic or promoter activity [4]. However, further studies are needed to investigate other mechanisms independent of Tet- $\mathrm{R}$ genes that contribute to Tet-R.

\section{Conclusion}

Taken together, our findings indicate the presence of multiple Tet-R genes in the genome of Lactobacillus isolates from human saliva, though most isolates do not show desired Tet-R. Several mutations in tet genes encoding ribosomal protection protein can affect gene expression. Exploring the mechanisms underlying this inconsistency between phenotypic resistance and genotype will be an interesting avenue for future research.

\footnotetext{
Abbreviations

CARD: Comprehensive antibiotic resistance database; MIC: Minimum inhibitory concentration; PCR: Polymerase chain reaction; qRTPCR: Quantitative real time- polymerase chain reaction; RPPS: Ribosomal protection proteins; SNP: Single nucleotide polymorphisms; TetR: Tetracycline resistance; WGS: Whole-genome sequencing
} 


\section{Acknowledgements}

Not applicable.

\section{Funding}

This study was supported by grants 81300880 from National Natural Science Foundation of China and grants PKUSS20170112 from the Peking University School of Stomatology.

\section{Availability of data and materials}

All analyzed data are included in this article.

\section{Authors' contributions}

YZ performed experiments and wrote the manuscript. QZ designed and analyzed the results. Both authors read and approved the final manuscript.

\section{Ethics approval and consent to participate}

The Institutional Review Board of Peking University School and Hospital of Stomatology approved the study protocol (approval number PKUSSIRB2013021). All participants provided their written informed consent to participate in this study.

\section{Consent for publication}

Not applicable.

\section{Competing interests}

The authors declare that they have no competing interests.

\section{Publisher's Note}

Springer Nature remains neutral with regard to jurisdictional claims in published maps and institutional affiliations.

\section{Received: 7 December 2018 Accepted: 30 January 2019} Published online: 04 February 2019

\section{References}

1. Aslam B, Wang W, Arshad Ml, Khurshid M, Muzammil S, Rasool MH, Nisar MA, Alvi RF, Aslam MA, Qamar MU, et al. Antibiotic resistance: a rundown of a global crisis. Infect Drug Resist. 2018;11:1645-58.

2. Berendonk TU, Manaia CM, Merlin C, Fatta-Kassinos D, Cytryn E, Walsh F, Burgmann H, Sorum H, Norstrom M, Pons MN, et al. Tackling antibiotic resistance: the environmental framework. Nat Rev Microbiol. 2015;13(5):310-7.

3. Gevers D, Huys G, Swings J. In vitro conjugal transfer of tetracycline resistance from lactobacillus isolates to other gram-positive bacteria. FEMS Microbiol Lett. 2003;225(1):125-30.

4. Chang YC, Tsai CY, Lin CF, Wang YC, Wang IK, Chung TC. Characterization of tetracycline resistance lactobacilli isolated from swine intestines at western area of Taiwan. Anaerobe. 2011;17(5):239-45.

5. Devirgiliis C, Zinno P, Perozzi G. Update on antibiotic resistance in foodborne lactobacillus and Lactococcus species. Front Microbiol. 2013;4:301.

6. Guo H, Pan L, Li L, Lu J, Kwok L, Menghe B, Zhang H, Zhang W. Characterization of antibiotic resistance genes from lactobacillus isolated from traditional dairy products. J Food Sci. 2017;82(3):724-30.

7. Palmer RJ Jr. Composition and development of oral bacterial communities. Periodontology 2000. 2014;64(1):20-39.

8. Roberts AP, Kreth J. The impact of horizontal gene transfer on the adaptive ability of the human oral microbiome. Front Cell Infect Microbiol. 2014;4:124.

9. Santoro F, Vianna ME, Roberts AP. Variation on a theme; an overview of the Tn916/Tn1545 family of mobile genetic elements in the oral and nasopharyngeal streptococci. Front Microbiol. 2014;5:535

10. Rams TE, Degener JE, van Winkelhoff AJ. Antibiotic resistance in human chronic periodontitis microbiota. J Periodontol. 2014;85(1):160-9.

11. Ardila CM, Granada MI, Guzman IC. Antibiotic resistance of subgingival species in chronic periodontitis patients. J Periodontal Res. 2010;45(4):557-63.

12. Nakayama A, Takao A. Beta-lactam resistance in Streptococcus mitis isolated from saliva of healthy subjects. J Infect Chemother. 2003;9(4):321-7.

13. Ready D, Pratten J, Roberts AP, Bedi R, Mullany P, Wilson M. Potential role of Veillonella spp. as a reservoir of transferable tetracycline resistance in the oral cavity. Antimicrob Agents Chemother. 2006;50(8):2866-8.

14. Zheng J, Ruan L, Sun M, Ganzle M. A genomic view of lactobacilli and Pediococci demonstrates that phylogeny matches ecology and physiology. Appl Environ Microbiol. 2015;81(20):7233-43.
15. Caufield PW, Schon CN, Saraithong P, Li Y, Argimon S. Oral lactobacilli and dental caries: a model for niche adaptation in humans. J Dent Res. 2015; 94(9 Suppl):110S-8S

16. Segata N, Haake SK, Mannon P, Lemon KP, Waldron L, Gevers D, Huttenhower C, Izard J. Composition of the adult digestive tract bacterial microbiome based on seven mouth surfaces, tonsils, throat and stool samples. Genome Biol. 2012;13(6):R42.

17. Zhang Y, Liu Y, Ma Q, Song Y, Zhang Q, Wang X, Chen F. Identification of lactobacillus from the saliva of adult patients with caries using matrixassisted laser desorption/ionization time-of-flight mass spectrometry. PLoS One. 2014;9(8):e106185.

18. Obata J, Takeshita T, Shibata Y, Yamanaka W, Unemori M, Akamine A, Yamashita Y. Identification of the microbiota in carious dentin lesions using 165 rRNA gene sequencing. PLoS One. 2014;9(8):e103712.

19. Zheng Y, Lu Y, Wang J, Yang L, Pan C, Huang Y. Probiotic properties of lactobacillus strains isolated from Tibetan kefir grains. PLoS One. 2013;8(7): e69868.

20. Caggia C, De Angelis M, Pitino I, Pino A, Randazzo CL. Probiotic features of lactobacillus strains isolated from Ragusano and pecorino Siciliano cheeses. Food Microbiol. 2015;50:109-17.

21. Devirgiliis C, Coppola D, Barile S, Colonna B, Perozzi G. Characterization of the Tn916 conjugative transposon in a food-borne strain of lactobacillus paracasei. Appl Environ Microbiol. 2009;75(12):3866-71.

22. Salminen $S$, von Wright A, Morelli L, Marteau P, Brassart D, de Vos WM, Fonden R, Saxelin M, Collins K, Mogensen G, et al. Demonstration of safety of probiotics -- a review. Int J Food Microbiol. 1998;44(1-2):93-106.

23. van Hoek AH, Mevius D, Guerra B, Mullany P, Roberts AP, Aarts HJ. Acquired antibiotic resistance genes: an overview. Front Microbiol. 2011;2:203.

24. Roberts AP, Mullany P. A modular master on the move: the Tn916 family of mobile genetic elements. Trends Microbiol. 2009:17(6):251-8.

25. Roberts MC. Update on acquired tetracycline resistance genes. FEMS Microbiol Lett. 2005;245(2):195-203.

26. Tribble GD, Garza JJ, Yeung VL, Rigney TW, Dao DH, Rodrigues PH, Walker CB, Smith CJ. Genetic analysis of mobile tetQ elements in oral Prevotella species. Anaerobe. 2010;16(6):604-9.

27. Okamoto M, Takano K, Maeda N. Distribution of the tetracycline resistance determinant tetQ gene in oral isolates of black-pigmented anaerobes in Japan. Oral Microbiol Immunol. 2001;16(4):224-8.

28. Rocas IN, Siqueira JF Jr. Detection of antibiotic resistance genes in samples from acute and chronic endodontic infections and after treatment. Arch Oral Biol. 2013;58(9):1123-8.

29. Lancaster $H$, Bedi R, Wilson M, Mullany P. The maintenance in the oral cavity of children of tetracycline-resistant bacteria and the genes encoding such resistance. J Antimicrob Chemother. 2005;56(3):524-31.

30. Mayrhofer S, Zitz U, Birru FH, Gollan D, Golos AK, Kneifel W, Domig KJ. Comparison of the CLSI guideline and ISO/IDF standard for antimicrobial susceptibility testing of lactobacilli. Microb Drug Resist. 2014;20(6):591-603.

31. Authority EFS. Technical guidance prepared by the panel on additives and products or substances used in animal feed (FEEDAP) on the update of the criteria used in the assessment of bacterial resistance to antibiotics of human or veterinary importance. EFSA J. 2008;732:1-15.

32. Arango-Argoty G, Garner E, Pruden A, Heath LS, Vikesland P, Zhang L. DeepARG: a deep learning approach for predicting antibiotic resistance genes from metagenomic data. Microbiome. 2018;6(1):23.

33. Abriouel H, Casado Munoz MDC, Lavilla Lerma L, Perez Montoro B, Bockelmann W, Pichner R, Kabisch J, Cho GS, Franz C, Galvez A, et al. New insights in antibiotic resistance of lactobacillus species from fermented foods. Food Res Int. 2015;78:465-81.

34. Ledina T, Mohar-Lorbeg P, Golob M, Djordjevic J, Bogovic-Matijasic B, Bulajic $S$. Tetracycline resistance in lactobacilli isolated from Serbian traditional raw milk cheeses. J Food Sci Technol. 2018:55(4):1426-34.

35. Strompfova $V$, Laukova A. Isolation and characterization of faecal bifidobacteria and lactobacilli isolated from dogs and primates. Anaerobe. 2014;29:108-12

36. Jena PK, Trivedi D, Thakore K, Chaudhary H, Giri SS, Seshadri S. Isolation and characterization of probiotic properties of lactobacilli isolated from rat fecal microbiota. Microbiol Immunol. 2013:57(6):407-16.

37. Jungermann GB, Burns K, Nandakumar R, Tolba M, Venezia RA, Fouad AF. Antibiotic resistance in primary and persistent endodontic infections. J Endod. 2011;37(10):1337-44. 
38. Villedieu A, Diaz-Torres ML, Hunt N, McNab R, Spratt DA, Wilson M, Mullany P. Prevalence of tetracycline resistance genes in oral bacteria. Antimicrob Agents Chemother. 2003;47(3):878-82.

39. Toomey N, Bolton D, Fanning S. Characterisation and transferability of antibiotic resistance genes from lactic acid bacteria isolated from lrish pork and beef abattoirs. Res Microbiol. 2010;161(2):127-35.

40. LeBlanc DJ, Lee LN, Titmas BM, Smith CJ, Tenover FC. Nucleotide sequence analysis of tetracycline resistance gene tetO from Streptococcus mutans DL5. J Bacteriol. 1988;170(8):3618-26.

41. Hentschke M, Christner M, Sobottka I, Aepfelbacher M, Rohde H. Combined ramR mutation and presence of a Tn1721-associated tet(A) variant in a clinical isolate of salmonella enterica serovar Hadar resistant to tigecycline. Antimicrob Agents Chemother. 2010;54(3):1319-22.

42. Tuckman M, Petersen PJ, Projan SJ. Mutations in the interdomain loop region of the tet $A(a)$ tetracycline resistance gene increase efflux of minocycline and glycylcyclines. Microb Drug Resist. 2000;6(4):277-82.

43. Nawaz M, Wang J, Zhou A, Ma C, Wu X, Moore JE, Millar BC, Xu J.

Characterization and transfer of antibiotic resistance in lactic acid bacteria from fermented food products. Curr Microbiol. 2011;62(3):1081-9.

44. Ammor MS, Gueimonde M, Danielsen M, Zagorec M, van Hoek AH, de Los Reyes-Gavilan CG, Mayo B, Margolles A. Two different tetracycline resistance mechanisms, plasmid-carried tet $(\mathrm{L})$ and chromosomally located transposonassociated tet(M), coexist in lactobacillus sakei Rits 9. Appl Environ Microbiol. 2008;74(5):1394-401.

Ready to submit your research? Choose BMC and benefit from:

- fast, convenient online submission

- thorough peer review by experienced researchers in your field

- rapid publication on acceptance

- support for research data, including large and complex data types

- gold Open Access which fosters wider collaboration and increased citations

- maximum visibility for your research: over $100 \mathrm{M}$ website views per year

At BMC, research is always in progress.

Learn more biomedcentral.com/submissions 